\title{
Impact of secondary succession in abandoned fields on some properties of acidic sandy soils
}

\author{
Lubomír Lichner $^{1 *}$, Massimo Iovino ${ }^{2}$, Peter Šurda ${ }^{1}$, Viliam Nagy ${ }^{1}$, Anton Zvala $^{1}$, Jozef Kollár ${ }^{3}$, \\ Jozef Pecho ${ }^{4}$, Vladimír Pís ${ }^{5}$, Nasrollah Sepehrnia ${ }^{6}$, Renáta Sándor ${ }^{7}$ \\ ${ }^{1}$ Institute of Hydrology, Slovak Academy of Sciences, Dúbravská cesta 9, 84104 Bratislava, Slovakia. \\ ${ }^{2}$ Dipartimento di Scienze Agrarie, Alimentari e Forestali, Università degli Studi di Palermo, Viale delle Scienze, Ed. 4 Ingr. E, \\ 90128 Palermo, Italy. \\ ${ }^{3}$ Institute of Landscape Ecology, Slovak Academy of Sciences, Štefánikova 3, 81499 Bratislava, Slovakia. \\ ${ }^{4}$ Slovak Hydrometeorological Institute, Jeséniova 17, 83315 Bratislava, Slovakia. \\ ${ }^{5}$ Soil Science and Conservation Research Institute, Trenčianska 55, 82109 Bratislava, Slovakia. \\ ${ }^{6}$ Institute of Soil Science, Leibniz Universität Hannover, Herrenhäuser Str. 2, D-30419 Hannover, Germany. \\ ${ }^{7}$ Agricultural Institute, Centre for Agricultural Research, Brunszvik u.2, 2462 Martonvásár, Hungary. \\ * Corresponding author. E-mail: lichner@uh.savba.sk
}

\begin{abstract}
Abandonment of agricultural lands in recent decades is occurring mainly in Europe, North America and Oceania, and changing the fate of landscapes as the ecosystem recovers during fallow stage. The objective of this study was to find the impact of secondary succession in abandoned fields on some parameters of acidic sandy soils in the Borská nížina lowland (southwestern Slovakia). We investigated soil chemical ( $\mathrm{pH}$ and soil organic carbon content), hydrophysical (water sorptivity, and hydraulic conductivity), and water repellency (water drop penetration time, water repellency cessation time, repellency index, and modified repellency index) parameters, as well as the ethanol sorptivity of the studied soils. Both the hydrophysical and chemical parameters decreased significantly during abandonment of the three investigated agricultural fields. On the other hand, the water repellency parameters increased significantly, but the ethanol sorptivity did not change during abandonment. As the ethanol sorptivity depends mainly on soil pore size, the last finding could mean that the pore size of acidic sandy soils did not change during succession.
\end{abstract}

Keywords: Water repellency; Acidic sandy soil; Land abandonment; Secondary succession; Soil properties.

\section{INTRODUCTION}

Farmland abandonment in recent decades (with about 210 million ha abandoned in 1990 (cf. Fig. 1 in Cramer et al., 2008)) is occurring mainly in Europe, North America and Oceania, with the most drastic decrease in agricultural lands (by about a third) seen in Europe (cf. Panel 1a in Queiroz et al., 2014). Land abandonment is a type of land use transformation that potentially causes the recovery of ecosystems (Cerdà et al., 2018). Passive revegetation in permanently abandoned arable land (called secondary succession) is characterized by the replacement of arable plant species by vegetation that disperse from surrounding habitats and will be subsequently established (Csecserits et al., 2011). Such secondary succession initially starts with annual or biannual plants, is then followed by perennial forbs, grasses and shrubs, and finally under usual Central European conditions ending up in a forest (climax stage).

Farmland abandonment represents a significant land use change from cropping to a complex of plant successions. Throughout most of Europe, vegetation on abandoned farmland has evolved into dense forest or shrub. The expansion of vegetation explains, in part, the perceived decline in water resources, reductions in soil loss and sediment delivery, and the progressive improvement of soil characteristics (García-Ruiz and Lana-Renault, 2011).

Vegetation change can also induce soil water repellency (SWR), which parameters are influenced by soil temperature (Novák et al., 2009), moisture (Leelamanie and Nishiwaki, 2019; Oostindie et al., 2017), texture (Benito et al., 2019), pH (Diehl et al., 2010), soil organic carbon (SOC) and clay (mainly kaolinite) content (Lichner et al., 2002). SWR may affect soil properties with depth (Orfánus et al., 2016; Sepehrnia et al., 2017) and time (Orfánus et al., 2014; Moret-Fernandez et al., 2019), and has positive effects on the stability of soil aggregates (Fér et al., 2016). Soil compaction may reduce SWR mainly as a consequence of decreased surface roughness (Bryant et al., 2007), but the hydrophobic conditions are readily restored a few days after removal of compaction load. Soil water repellency can be alleviated by addition of lime (Roper, 2005), kaolinite clay (Lichner et al., 2002; McKissock et al., 2000), and wax degrading bacteria (Roper, 2006). Naveed et al. (2019) found that the large impact of plant exudates and mucilages on water retention characteristics could be explained by differences in surface tension, contact angle and viscosity between exudates and mucilages of different origin. These properties may be driven by the relative amounts of organic acids and sugars (free and polysaccharide derived) in the exudates and mucilages. Guo et al. (2016) and Nik et al. (2015) also found the chemical composition of SOC changes during vegetation evolution.

Primary succession was found to increase SWR parameters and SOC content in acidic sandy soils in the Borská nížina lowland, Slovakia (Lichner et al., 2018), however there is a lack of knowledge in terms of secondary succession. The objective of this research was thus to estimate the effects of secondary succession during 28 years lasting abandonment of agricultural fields on chemical ( $\mathrm{pH}$ and SOC content), hydrophysical (water sorptivity and hydraulic conductivity), and water repellency parameters (water drop penetration time, water repellency cessation time, repellency index, and modified repellency index), 


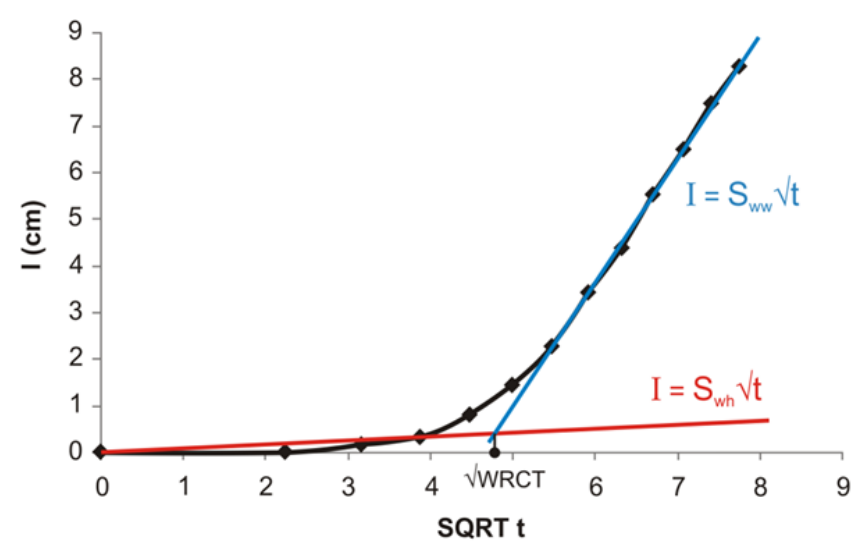

Fig. 1. The hockey-stick-like relationship of the cumulative infiltration of water $(I)$ against the square root of time (SQRT $t$ ) for a sandy soil. The water sorptivity $S_{w h}(-2 \mathrm{~cm})$ for water-repellent state of soil and the water sorptivity $S_{w w}(-2 \mathrm{~cm})$ for nearly wettable state of soil were estimated, respectively, from the two different slopes of the relationship. The water repellency cessation time (WRCT) was estimated from the point of intersection of two straight lines, representing the $I=f(\mathrm{SQRT} t)$ relationships for water-repellent and nearly wettable states of the soil.

as well as ethanol sorptivity of the top layer of three acidic sandy soils in the Borská nížina lowland, Slovakia. We hypothesize that the soil chemical and hydrophysical parameters will decrease, while the soil water repellency parameters will increase with the duration of abandonment.

\section{MATERIAL AND METHODS Study sites}

The experimental sites S1, S2 are located at Sekule village (48 36'58.2' ' N, 16 ${ }^{\circ} 59^{\prime} 39.0^{\prime}$ ' E), while the experimental site $\mathrm{S} 3$ is placed at Studienka village $\left(48^{\circ} 31^{\prime} 49.3^{\prime \prime}\right.$ N, $17^{\circ} 08^{\prime} 34.5^{\prime}$ ' E) in the Borská nížina lowland (southwestern Slovakia). The closest distance between the sites in Sekule and Studienka is about $12 \mathrm{~km}$. According to the Köppen-Geiger climate classification, the region has temperate climate without dry season, warm summer (Cfb) (Kottek et al., 2006). Mean annual precipitation is about $550 \mathrm{~mm}$, which is mainly summer-dominant. Elevation is $158 \mathrm{~m}$ a.s.l. at Sekule and $299 \mathrm{~m}$ a.s.l. at Studienka. Site S1 was a cultivated agricultural area planted with barley (Hordeum vulgare L.) in 2017. Site S2, abandoned for 12 years, is an early succession stage dominated by psammophilous grass Corynephorus canescens (L.) P. Beauv. with an admixture of other psammophytes and sand-tolerant weeds, such as Bromus tectorum L., Cerastium semidecandrum L., Acetosella vulgaris Fourr., Anthemis ruthenica M. Bieb., Conyza canadensis (L.) Cronquist, Filago arvensis L., Myosotis stricta Link ex Roem. et Schult., Setaria pumila (Poir.) Roem. et Schult., Spergula morisonii Boreau, Trifolium arvense L., Veronica dillenii Crantz, Chondrilla juncea L., and Crepis sp. Site S3 is a former arable land abandoned for 28 years. It is covered by synanthropized grassland dominated by Festuca rupicola Heuff. and Chondrilla juncea L., which are accompanied by admixture of psammophilous species (e.g. Corynephorus canescens (L.) P. Beauv., Jasione montana L., Acetosella vulgaris Fourr.) and sand-tolerant weeds (e. g. Calamagrostis epigejos (L.) Roth, Setaria pumila (Poir.) Roem. et Schult., Conyza canadensis (L.) Cronquist). The soils of the Sekule and Studienka sites are classified as Arenosol (WRB, 2014) and have sandy texture (Soil Survey Division Staff, 1993).

\section{Methods \\ Laboratory methods}

Basic soil properties were determined on disturbed samples with two replicates in the ISO Certified Laboratory of the Soil Science and Protection Research Institute in Bratislava. Particle size distribution was determined by sieving and sedimentation according to ISO 11277 (2009), $\mathrm{pH}(\mathrm{KCl})$ and $\mathrm{pH}\left(\mathrm{H}_{2} 0\right)$ were measured according to ISO 10390 (2005), SOC content was determined by oxidation with $\mathrm{K}_{2} \mathrm{Cr}_{2} \mathrm{O}_{7}-\mathrm{H}_{2} \mathrm{SO}_{4}$ and titration of non-reduced dichromate according to ISO 10694 (1995), and carbonate content was determined from the volume of $\mathrm{CO}_{2}$, produced during the decomposition of carbonates with about $10 \%$ hydrochloric acid, according to ISO 10693 (1995). The disturbed soil samples were taken randomly within an area of $25 \mathrm{~m}^{2}$ in the surface $(0-5 \mathrm{~cm})$ layer at $\mathrm{S} 1$ site on 2 August 2018 , at S2 site on 30-31 July 2018, and at S3 site on 9 October 2018.

\section{Field methods}

All the measurements of soil hydrophysical and SWR parameters were carried out on the surface of the studied soils during the hot and dry spell and the number of their replicates is presented in Table 2. The above-mentioned parameters were measured and the disturbed soil samples for laboratory determination of physical and chemical properties were taken from the top $(0-5 \mathrm{~cm})$ layer on 2 August 2018 (Site S1), 30-31 July 2018 (Site S2), and 9 October 2018 (Site S3). The places for the infiltration runs were chosen in the neighbourhood of each vegetal species and the surface to put the infiltrometers was flattened.

The volumetric water content, $w(\% \mathrm{vol})$, of the superficial $(0-5 \mathrm{~cm})$ soil layer was measured with a moisture meter type HH2 and soil moisture sensor SM200 (Delta-T Devices Ltd, Cambridge, UK).

Field water and ethanol infiltration measurements were performed with a minidisk infiltrometer (MDI) (Decagon, 2012) under a negative tension $h_{0}=-2 \mathrm{~cm}$ (Alagna et al. 2017, 2019). The cumulative infiltration $I$ was calculated based on the Philip infiltration equation:

$I=C_{1} t^{1 / 2}+C_{2} t+C_{3} t^{3 / 2}+\ldots+C_{m} t^{\mathrm{m} / 2}+\ldots$

where $C_{1}, C_{2}, C_{3}, \ldots$, and $C_{m}$ are coefficients, and $t$ is time.

The sorptivity, $S(-2 \mathrm{~cm})$, was estimated from the first term of the Philip infiltration equation $\left(I=C_{1} t^{1 / 2}\right)$ during early-time infiltration of water and ethanol (Clothier et al., 2000):

$S(-2 \mathrm{~cm})=I / t^{0.5}$

Duration of early-time infiltration is $60-180 \mathrm{~s}$ for a wettable $(\mathrm{WDPT}=0-5 \mathrm{~s})$ and slightly repellent $(\mathrm{WDPT}=5-60 \mathrm{~s})$ soil (Hallett, 2008), or it is equal to the time of passing the first five bubbles (with the total volume of about $1 \mathrm{~mL}$ ) through MDI (Time to First Five Bubbles, TFFB, in Beatty and Smith, 2014) for strongly (WDPT $=60-600 \mathrm{~s}$ ), severely (WDPT $=600-3600$ $\mathrm{s}$ ), and extremely (WDPT $>3600 \mathrm{~s}$ ) water repellent soils. During this time the process is dominated by the capillarity and the other terms of the Philip infiltration equation can be neglected.

Equation (2) was used to calculate both the water sorptivity $\left(S_{w}(-2 \mathrm{~cm})\right)$ and ethanol sorptivity $\left(S_{e}(-2 \mathrm{~cm})\right)$ from the cumulative infiltration $v s$. time relationships taken from the MDI measurements. It was found that $S_{w}$ is not function of water source tension, but is function of initial soil water content. The highest value of $S_{w}$ corresponded to the lowest soil water con- 
tent, remaining practically constant in a large range of soil water content, and abruptly decreasing near saturation toward zero (Villarreal et al., 2019). It should be mentioned that the water sorptivity depends on SWR and soil pore size, and ethanol sorptivity depends mainly on soil pore size.

The repellency index RI (Decagon, 2012; Hallett and Young, 1999; Lichner et al., 2007)

$\mathrm{RI}=1.95 S_{e}(-2 \mathrm{~cm}) / S_{w}(-2 \mathrm{~cm})$

was estimated from the combination of all the ethanol and water sorptivities, i.e., $\mathrm{m} \times \mathrm{n}$ values of RI were calculated from $\mathrm{m}$ values of $S_{w}(-2 \mathrm{~cm})$ and $\mathrm{n}$ values of $S_{e}(-2 \mathrm{~cm})$ (Pekárová et al., 2015). The RI values correlated closely with water drop penetration time (WDPT), which was used to develop a classification of RI by Iovino et al. (2018).

In the second method of estimating the RI, the water sorptivity $S_{w h}(-2 \mathrm{~cm})$ for water-repellent state of soil and the water sorptivity $S_{w w}(-2 \mathrm{~cm})$ for nearly wettable state of soil were estimated, respectively, from the slopes of the initial and subsequent stages of hockey-stick-like relationship (Fig. 1), and used to calculate a modified repellency index $\mathrm{RI}_{\mathrm{m}}$ (Sepehrnia et al., 2016):

$\mathrm{RI}_{\mathrm{m}}=S_{w w}(-2 \mathrm{~cm}) / S_{w h}(-2 \mathrm{~cm})$

The persistence of SWR was assessed by both the WDPT and water repellency cessation time, WRCT (Lichner et al., 2013). The WDPT test involves placing a $50 \pm 5 \mu \mathrm{L}$ water drop from a standard medicine dropper or pipette on the soil surface and recording the time of its complete penetration. A standard droplet release height of approximately $10 \mathrm{~mm}$ above the soil surface was used to minimize the cratering effect on the soil surface (Doerr, 1998; Tinebra et al., 2019). The following classes of the persistence of SWR were distinguished: wettable or non-water-repellent soil (WDPT $<5 \mathrm{~s}$ ), slightly (WDPT $=5-60$ $\mathrm{s})$, strongly (WDPT $=60-600 \mathrm{~s})$, severely $(\mathrm{WDPT}=600-3600$ $\mathrm{s}$ ), and extremely (WDPT $>3600 \mathrm{~s}$ ) water repellent soil (Bisdom et al., 1993). The values of WRCT were estimated from the intersection of two straight lines, representing the two stages of infiltration (Fig. 1).

Field water infiltration measurements with the MDI under a negative tension $h_{0}=-2 \mathrm{~cm}$ were used to estimate the hydraulic conductivity $k(-2 \mathrm{~cm})$. Zhang (1997) proposed to use the first two terms of the Philip infiltration equation to fit the cumulative infiltration $v s$. time relationship and estimate the hydraulic conductivity $k(-2 \mathrm{~cm})$ from equation:

$k(-2 \mathrm{~cm})=C_{2} / A$

where $A$ is a dimensionless coefficient. Fitting of the two terms infiltration equation to cumulative infiltration data was performed through the linearization technique suggested by the Minidisk Infiltrometer User's Manual (Decagon, 2012). A value of $A=1.73$, corresponding to sandy soil and suction $h_{0}=-2 \mathrm{~cm}$, was used to calculate the hydraulic conductivity $k(-2 \mathrm{~cm})$. Given capillarity can be ignored at long times, estimation of $k$ is expected to be more accurate as $t$ increases (Zhang, 1997). The MDI experiments were therefore conducted until apparent steady state conditions were observed.

\section{Statistical treatment}

The statistical analysis to find differences between the parameters estimated in different sites was performed with NCSS 12 Statistical Software (2018), using single factor ANOVA and
Tukey's Honestly Significant Difference (HSD) post-hoc test $(\mathrm{p}<0.05)$. The Tukey-Kramer method (also known as Tukey's HSD (Honest Significant Difference) method) uses the Studentized Range distribution to compute the adjustment to $c_{\alpha}$. The Tukey-Kramer method achieves the exact alpha level (and simultaneous confidence level $(1-\alpha)$ ) if the group sample sizes are equal and is conservative if the sample sizes are unequal. The Tukey-Kramer test is one of the most powerful all-pairs testing procedures and is widely used.

The Tukey-Kramer adjusted critical value for tests and simultaneous confidence intervals is

$c_{\alpha}=\frac{q_{1-\alpha, k, v}}{\sqrt{2}}$

where $q_{1-\alpha, k, v}$ is the $1-\alpha$ quantile of the studentized range distribution.

\section{RESULTS AND DISCUSSION}

Basic soil-physical and chemical properties are presented in Table 1. A decrease in $\mathrm{pH}$ value of the studied soils from 6.55 to 4.50 was registered after 28-year lasting abandonment of agricultural fields in southwestern Slovakia. The great decrease in $\mathrm{pH}$ value in the studied abandoned fields is consistent with the findings of Zhao et al. (2014) during progressive succession of vegetation (grassland, shrubland, forest) occurring in karst sites in southwestern China, as well as Bautista-Cruz and del Castillo (2005) during the development of second-growth forest after abandonment of agricultural fields in tropical montane cloud forest areas in southern Mexico.

The significant decrease in $\mathrm{pH}$ value during abandonment was accompanied with the significant decrease in SOC content (Table 1) and significant increase in SWR parameters (Table 2), indicating that the composition of organic matter and its overall effectiveness to influence the wetting properties of soil particles is more important than the total amount of soil organic carbon (Ellerbrock et al., 2005). It should be mentioned that the SOC content in the top layer of acidic sandy soil under grass cover in Studienka is about 2-times less than the SOC content in the top layer of acidic silt loam soil under grass cover in Hněvčeves, the Czech Republic (0.80\% vs. 1.74\%) (Kodešová et al., 2011). Substantially higher clay and silt content in the top layer of Hněvčeves soil in comparison with that of Studienka soil $(87.72 \%$ vs. $3.52 \%)$ resulted in better ability to accumulate organic matter.

Statistical characteristics of soil hydrophysical parameters $\left(k(-2 \mathrm{~cm})\right.$ and $\left.S_{w}(-2 \mathrm{~cm})\right)$, ethanol sorptivity, $S_{e}(-2 \mathrm{~cm})$, and soil water repellency parameters (WDPT, WRCT, RI, and $\mathrm{RI}_{\mathrm{m}}$ ) of the top layer of acidic sandy soils from the sites S1, S2 (Sekule, Slovakia), and S3 (Studienka, Slovakia) are presented in Table 2. As to the hydrophysical and chemical parameters, the mean value of $S_{w}(-2 \mathrm{~cm})$ decreased about 2.8 times, $k(-2 \mathrm{~cm})$ about 15.6 times, and SOC content about 2.3 times, while $S_{e}(-2 \mathrm{~cm})$ did not change significantly after 28 years lasting abandonment of agricultural field with acidic sandy soil in the Borská nížina lowland, Slovakia. As the ethanol sorptivity depends mainly on soil pore size, the last finding could mean that the soil pore size of acidic sandy soil did not change during succession. Soil structure is poorly developed in sandy soils whereas soil compaction due to human activity was negligible, thus pore size distribution is mainly determined by particle size distribution that is a relatively stable soil property at this time scale (Table 1$)$. The results of $S_{w}(-2 \mathrm{~cm})(0.679 \pm 0.469$ $\left.\mathrm{mm} \mathrm{s}^{-1 / 2}\right)$ and $k(-2 \mathrm{~cm})\left(9.1 \pm 7.5 \mu \mathrm{m} \mathrm{s}^{-1}\right)$ estimated in acidic 
sandy soil at the 28 years abandoned agricultural field covered with grass created by secondary succession at Studienka are not significantly different from the results of $S_{w}(-2 \mathrm{~cm})$ $\left(1.14 \pm 0.677 \mathrm{~mm} \mathrm{~s}^{-1 / 2}\right)$ and $k(-2 \mathrm{~cm})\left(48.0 \pm 35.0 \mu \mathrm{m} \mathrm{s}^{-1}\right)$ estimated in an acidic sandy soil under grass created by primary succession at Sekule (Šurda et al., 2015). It could mean that the values of hydraulic conductivity and water sorptivity of acidic sandy soil under grass do not depend on the type (primary or secondary) of succession resulting in the grass cover.

As to the soil water repellency parameters, the mean value of WDPT increased about 747 times, WRCT about 229 times, RI about 14 times, and $\mathrm{RI}_{\mathrm{m}}$ about 2.5 times after 28 years lasting abandonment of agricultural field with acidic sandy soil in the Borská nížina lowland, Slovakia. The increase in WDPT is consistent with the findings of Hewelke (2019) who registered an increase in WDPT after excluding albic Podzols from agricultural production. The results of WDPT $(949 \pm 568 \mathrm{~s})$ and RI (35.0 \pm 58.7$)$ estimated in acidic sandy soil at the 28 years abandoned agricultural field covered with grass created by secondary succession at Studienka are, respectively, smaller and higher than the results of WDPT $(1723 \pm 1610$ s) and RI (4.27 \pm 2.05$)$ estimated in acidic sandy soil under grass created by primary succession at Sekule (Šurda et al., 2015).

Dependence of soil parameters on the duration of field abandonment for the southwestern Slovakia sites is presented on Fig. 2. It can be seen that $\mathrm{pH}, S_{w}(-2 \mathrm{~cm})$, and $k(-2 \mathrm{~cm})$ decreased continuously, WDPT, WRCT, RI, and $\mathrm{RI}_{\mathrm{m}}$ increased continuously, while $S_{e}(-2 \mathrm{~cm})$ did not change significantly with the duration of field abandonment. A similar course of soil parameters was observed during the primary succession in acidic sandy soils in Sekule and Mehlinger Heide, Germany (Lichner et al., 2018). Rather than the continuous increase or decrease in soil parameters with duration of field abandonment, a "zigzag" pattern of all but one $\left(S_{e}(-2 \mathrm{~cm})\right)$ soil parameter relationships was registered during the 44 years lasting abandonment of agricultural field with alkaline sandy soils in Csólyospálos, Hungary (Lichner et al., 2018). This can be explained by the different vegetation cover and the resulting changes in the vegetation uptake of fertilizers and production of root exudates (cf. Naveed et al., 2019) and thatch.

Table 1. Physical and chemical properties of the top $(0-5 \mathrm{~cm})$ soils taken from the experimental sites $\mathrm{S} 1, \mathrm{~S} 2$, and $\mathrm{S} 3$. The results are presented in the form: arithmetic mean \pm standard deviation. (SOC - soil organic carbon).

\begin{tabular}{lccc}
\hline Attribute & S1 & S2 & S3 \\
\hline Clay $(\%)$ & $3.663 \pm 0.936$ & $2.126 \pm 0.202$ & $2.750 \pm 0.607$ \\
Silt $1-10 \mu \mathrm{m}(\%)$ & $5.232 \pm 0.483$ & $1.886 \pm 0.226$ & $0.100 \pm 0.017$ \\
Silt $10-50 \mu \mathrm{m}(\%)$ & $6.641 \pm 0.934$ & $1.605 \pm 0.424$ & $0.673 \pm 0.085$ \\
Sand $50-250 \mu \mathrm{m}(\%)$ & $25.952 \pm 4.121$ & $20.608 \pm 3.511$ & $26.607 \pm 2.052$ \\
Sand $0.25-2 \mathrm{~mm}(\%)$ & $58.516 \pm 6.479$ & $73.775 \pm 4.364$ & $69.870 \pm 2.761$ \\
$\mathrm{CaCO}_{3}(\%)$ & $<0.05$ & $0.10 \pm 0.03$ & $<0.05$ \\
$\mathrm{SOC}(\%)$ & $1.80^{\mathrm{a}} \pm 0.11$ & $1.06^{\mathrm{b}} \pm 0.04$ & $0.80^{\mathrm{b}} \pm 0.06$ \\
$\mathrm{pH}\left(\mathrm{H}_{2} \mathrm{O}\right)$ & $6.55^{\mathrm{a}} \pm 0.06$ & $5.60^{\mathrm{b}} \pm 0.03$ & $4.50^{\mathrm{c}} \pm 0.03$ \\
$\mathrm{pH}(\mathrm{KCl})$ & $6.25^{\mathrm{a}} \pm 0.03$ & $4.20^{\mathrm{b}} \pm 0.03$ & $4.16^{\mathrm{b}} \pm 0.01$ \\
\hline
\end{tabular}

Properties denoted with different letters are significantly different on significance level 0.05 .

Table 2. Statistical characteristics of soil hydrophysical parameters (namely the hydraulic conductivity, $k(-2 \mathrm{~cm})$, water sorptivity, $S_{w}(-2 \mathrm{~cm})$, and ethanol sorptivity, $S_{e}(-2 \mathrm{~cm})$ ) and soil water repellency parameters (namely the water drop penetration time, WDPT, water repellency cessation time, WRCT, repellency index, RI, and modified repellency index, $\mathrm{RI}_{\mathrm{m}}$ ) of the top layer of acidic soils from the sites $\mathrm{S} 1, \mathrm{~S} 2$, and S3.

\begin{tabular}{|c|c|c|c|c|c|c|c|}
\hline Site & Attribute & Minimum & Maximum & Median & Mean & Standard deviation & $\begin{array}{c}\text { Number } \\
\text { of replicates }\end{array}$ \\
\hline \multirow[t]{8}{*}{ S1 } & $w(\%$ vol $)$ & $<0.1$ & $<0.1$ & $<0.1$ & $<0.1$ & $<0.1$ & 10 \\
\hline & $k(-2 \mathrm{~cm})\left(\mu \mathrm{m} \mathrm{s}^{-1}\right)$ & 6.6 & 228 & 158 & $142^{\mathrm{a}}$ & 66 & 10 \\
\hline & $S_{w}(-2 \mathrm{~cm})\left(\mathrm{mm} \mathrm{s}^{-1 / 2}\right)$ & 1.31 & 2.42 & 1.94 & $1.89^{\mathrm{a}}$ & 0.35 & 10 \\
\hline & $S_{e}(-2 \mathrm{~cm})\left(\mathrm{mm} \mathrm{s}^{-1 / 2}\right)$ & 2.10 & 2.63 & 2.29 & $2.33^{\mathrm{a}}$ & 0.25 & 4 \\
\hline & WDPT (s) & 1 & 2 & 1 & $1.27^{\mathrm{a}}$ & 0.47 & 11 \\
\hline & WRCT (s) & 5.10 & 8.77 & 6.45 & $6.68^{\mathrm{a}}$ & 1.45 & 10 \\
\hline & $\mathrm{RI}(-)$ & 1.69 & 3.91 & 2.32 & $2.49^{\mathrm{a}}$ & 0.57 & 40 \\
\hline & $\mathrm{RI}_{\mathrm{m}}(-)$ & 2.54 & 5.91 & 5.19 & $4.59^{\mathrm{a}}$ & 1.27 & 10 \\
\hline \multirow[t]{8}{*}{$\mathrm{S} 2$} & $w(\% \mathrm{vol})$ & $<0.1$ & $<0.1$ & $<0.1$ & $<0.1$ & $<0.1$ & 10 \\
\hline & $k(-2 \mathrm{~cm})\left(\mu \mathrm{m} \mathrm{s}^{-1}\right)$ & 12.7 & 69.4 & 46.6 & $42.3^{\mathrm{b}}$ & 24.4 & 10 \\
\hline & $S_{w}(-2 \mathrm{~cm})\left(\mathrm{mm} \mathrm{s}^{-1 / 2}\right)$ & 0.42 & 1.48 & 1.08 & $1.03^{\mathrm{b}}$ & 0.38 & 10 \\
\hline & $S_{e}(-2 \mathrm{~cm})\left(\mathrm{mm} \mathrm{s}^{-1 / 2}\right)$ & 1.49 & 2.39 & 2.09 & $2.01^{\mathrm{a}}$ & 0.40 & 4 \\
\hline & WDPT (s) & 2 & 1520 & 20 & $179^{\mathrm{a}}$ & 448 & 11 \\
\hline & WRCT (s) & 8.8 & 99.6 & 33.4 & $36.5^{\mathrm{a}}$ & 25.5 & 10 \\
\hline & $\mathrm{RI}(-)$ & 2.0 & 11.1 & 3.64 & $4.59^{\mathrm{a}}$ & 2.54 & 40 \\
\hline & $\mathrm{RI}_{\mathrm{m}}(-)$ & 3.5 & 13.4 & 4.82 & $5.62^{\mathrm{a}, \mathrm{b}}$ & 2.96 & 10 \\
\hline \multirow[t]{8}{*}{ S3 } & $w(\% \mathrm{vol})$ & $<0.1$ & 3.0 & 0.45 & 0.79 & 1.06 & 10 \\
\hline & $k(-2 \mathrm{~cm})\left(\mu \mathrm{m} \mathrm{s}^{-1}\right)$ & 0 & 19.7 & 9.0 & $9.1^{\mathrm{b}}$ & 7.5 & 10 \\
\hline & $S_{w}(-2 \mathrm{~cm})\left(\mathrm{mm} \mathrm{s}^{-1 / 2}\right)$ & 0.02 & 1.21 & 0.83 & $0.68^{\mathrm{b}}$ & 0.47 & 10 \\
\hline & $S_{e}(-2 \mathrm{~cm})\left(\mathrm{mm} \mathrm{s}^{-1 / 2}\right)$ & 1.93 & 2.39 & 2.01 & $2.08^{\mathrm{a}}$ & 0.21 & 4 \\
\hline & WDPT (s) & 20 & 1960 & 980 & $949^{\mathrm{b}}$ & 568 & 15 \\
\hline & WRCT (s) & 61.9 & 4172 & 1065 & $1572^{\mathrm{b}}$ & 1463 & 9 \\
\hline & $\mathrm{RI}(-)$ & 3.1 & 221 & 5.1 & $35.0^{\mathrm{b}}$ & 58.7 & 40 \\
\hline & $\mathrm{RI}_{\mathrm{m}}(-)$ & 3.6 & 30.8 & 6.6 & $11.4^{\mathrm{b}}$ & 9.5 & 9 \\
\hline
\end{tabular}

Properties denoted with different letters are significantly different on significance level 0.05 . 


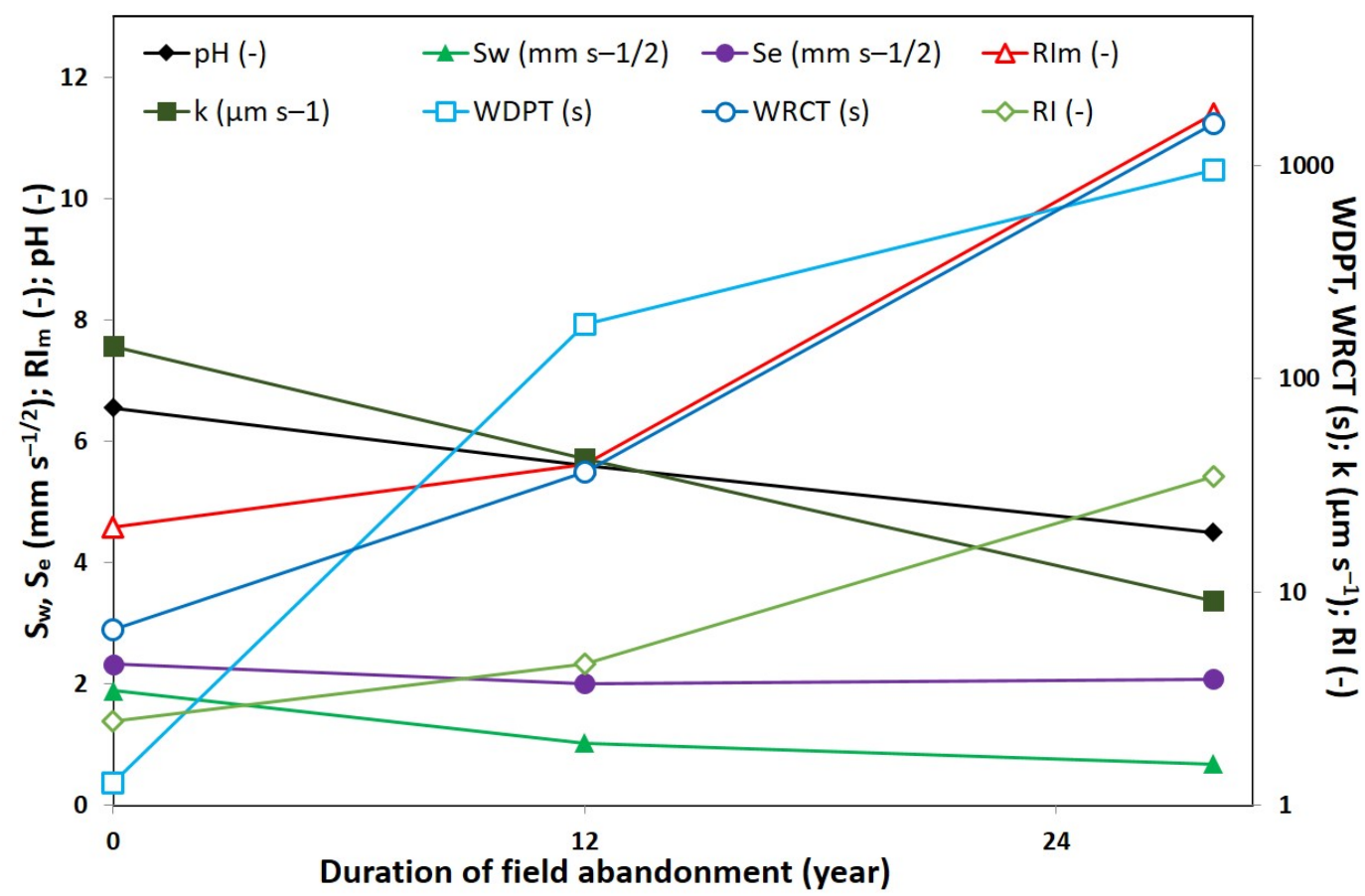

Fig. 2. Soil water repellency parameters (water drop penetration time, WDPT, water repellency cessation time, WRCT, repellency index, $\mathrm{RI}$, and modified repellency index, $\left.\mathrm{RI}_{\mathrm{m}}\right)$ and soil hydrophysical parameters (hydraulic conductivity, $k(-2 \mathrm{~cm})$, water sorptivity, $S_{w}(-2 \mathrm{~cm})$, and ethanol sorptivity, $S_{e}(-2 \mathrm{~cm})$ ) of the top layer of acidic soils vs. duration of field abandonment relationships for the southwestern Slovakia sites.

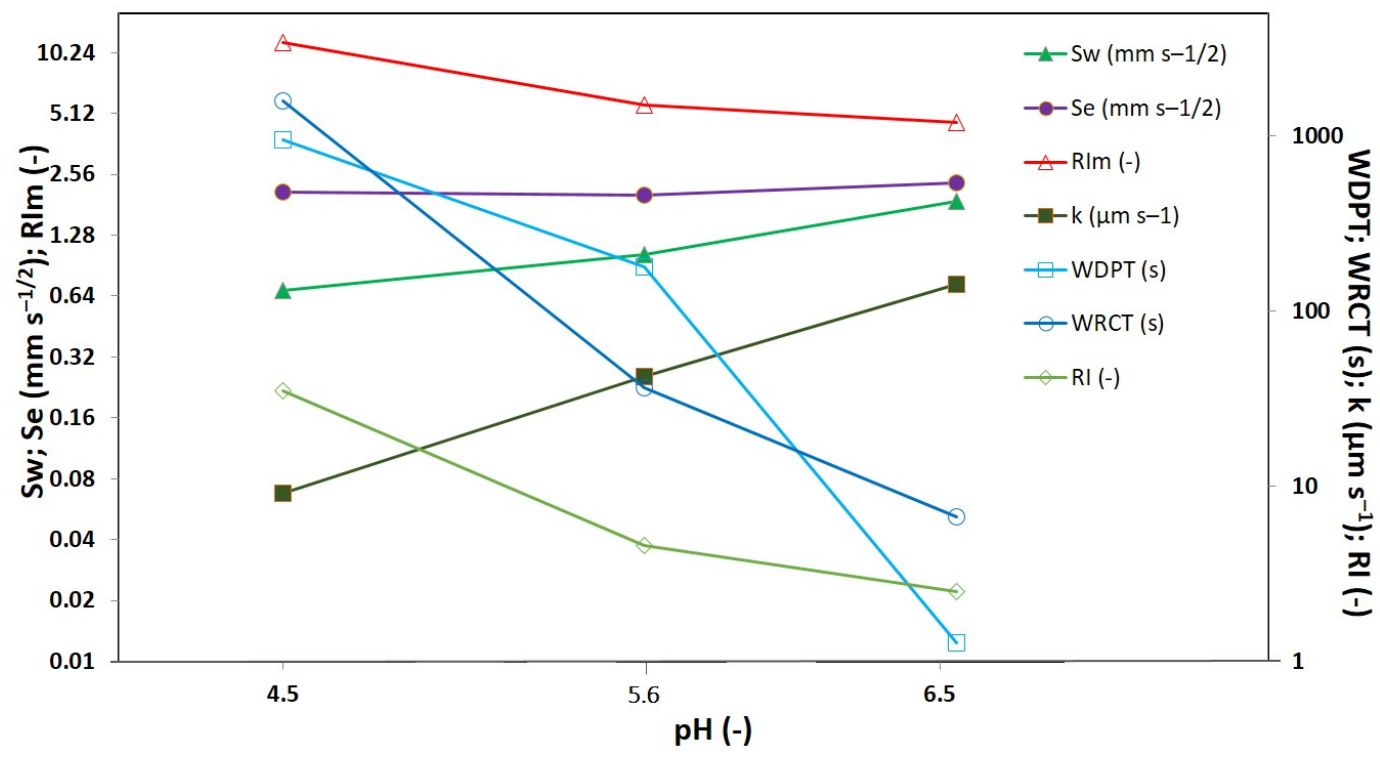

Fig. 3. Soil water repellency parameters (water drop penetration time, WDPT, water repellency cessation time, WRCT, repellency index, $\mathrm{RI}$, and modified repellency index, $\left.\mathrm{RI}_{\mathrm{m}}\right)$ and soil hydrophysical parameters (hydraulic conductivity, $k(-2 \mathrm{~cm})$, water sorptivity, $S_{w}(-2 \mathrm{~cm})$, and ethanol sorptivity, $S_{e}(-2 \mathrm{~cm})$ ) of the top layer of acidic soils vs. $\mathrm{pH}$ relationships for the southwestern Slovakia sites.

Dependence of soil parameters on $\mathrm{pH}$ for the southwestern Slovakia sites is presented on Fig. 3. It can be seen that $S_{w}(-2 \mathrm{~cm})$, and $k(-2 \mathrm{~cm})$ increased continuously, WDPT, WRCT, RI, and $\mathrm{RI}_{\mathrm{m}}$ decreased continuously, while $S_{e}(-2 \mathrm{~cm})$ did not change significantly with $\mathrm{pH}$. The decrease in WDPT with an increase in $\mathrm{pH}$ value in the studied abandoned fields is consistent with the findings of Diehl et al. (2010).

\section{CONCLUSION}

Abandonment of agricultural fields with acidic sandy soil in the Borská nížina lowland, Slovakia, results in a significant decrease in the hydrophysical (water sorptivity and hydraulic conductivity) and chemical (pH and soil organic carbon content) parameters, significant increase in the water repellency 
(water drop penetration time, water repellency cessation time, repellency index, and modified repellency index) parameters, but insignificant change in the ethanol sorptivity. As the ethanol sorptivity depends mainly on soil pore size, the last finding could mean that the soil pore size of acidic sandy soil did not change during succession.

Acknowledgements. The authors thank Prof. Kodešová and two anonymous reviewers for their wise comments and suggestions, which helped to improve the paper. This work was supported by the Slovak Scientific Grant Agency VEGA Project 2/0189/17, the Slovak Research and Development Agency Project APVV-15-0160, and the János Bolyai Research Scholarship of the Hungarian Academy of Sciences.

\section{REFERENCES}

Alagna, V., Iovino, M., Bagarello, V., Mataix-Solera, J., Lichner, L., 2017. Application of minidisk infiltrometer to estimate water repellency in Mediterranean pine forest soils. Journal of Hydrology and Hydromechanics, 65, 254-263.

Alagna, V., Iovino, M., Bagarello, V., Mataix-Solera, J., Lichner, L., 2019. Alternative analysis of transient infiltration experiment to estimate soil water repellency. Hydrological Processes, 33, 661-674.

Bautista-Cruz, A., del Castillo, R.F., 2005. Soil changes during secondary succession in a tropical montane cloud forest area. Soil Science Society of America Journal, 69, 906-914.

Beatty, S.M., Smith, J.E., 2014. Infiltration of water and ethanol solutions in water repellent post wildfire soils. Journal of Hydrology, 514, 233-248.

Benito, E., Varela, E., Rodríguez-Alleres, M., 2019. Persistence of water repellency in coarse-textured soils under various types of forests in NW Spain. Journal of Hydrology and Hydromechanics, 67, 129-134.

Bisdom, E.B.A., Dekker, L.W., Schoute, J.F.T., 1993. Water repellency of sieve fractions from sandy soils and relationships with organic material and soil structure. Geoderma, 56, 105-118.

Bryant, R., Doerr, S.H., Hunt, G., Conan, S., 2007. Effects of compaction on soil surface water repellency. Soil Use and Management, 23, 238-244.

Cerdà, A., Rodrigo-Comino, J., Novara, A., Brevik, E.C., Vaezi, A.R., Pulido, M., Giménez-Morera, A., Keesstra, S.D., 2018. Long-term impact of rainfed agricultural land abandonment on soil erosion in the Western Mediterranean basin. Progress in Physical Geography: Earth and Environment, 42, 202-219.

Clothier, B.E., Vogeler, I., Magesan, G.N., 2000. The breakdown of water repellency and solute transport through a hydrophobic soil. Journal of Hydrology, 231-232, 255-264.

Cramer, V.A., Hobbs, R.J., Standish, R.J., 2008. What's new about old fields? Land abandonment and ecosystem assembly. Trends in Ecology and Evolution, 23, 104-112.

Csecserits, A., Czucz, B., Halassy, M., Kröel-Dulay, G., Rédei, T., Szabó, R., Szitár, K., Török, K., 2011. Regeneration of sandy old-fields in the forest steppe region of Hungary. Plant Biosystems, 145, 715-729.

Decagon, 2012. Mini Disk Infiltrometer - User's Manual. Version 10. Decagon Devices, Inc., Pullman.

Diehl, D., Bayer, J.V., Woche, S.K., Bryant, R., Doerr, S.H., Schaumann, G.E., 2010. Reaction of soil water repellency to artificially induced changes in soil pH. Geoderma, 158, 375384.

Doerr, S.H., 1998. On standardizing the "Water Drop Penetration
Time" and the "Molarity of an Ethanol Droplet" techniques to classify soil hydrophobicity: a case study using medium textured soils. Earth Surface Processes and Landforms, 23, 663-668.

Ellerbrock, R.H., Gerke, H.H., Bachmann, J., Goebel, M.-O., 2005. Composition of organic matter fractions for explaining wettability of three forest soils. Soil Science Society of America Journal, 69, 57-66.

Fér, M., Leue, M., Kodešová, R., Gerke, H.H., Ellerbrock, R.H., 2016. Droplet infiltration dynamics and soil wettability related to soil organic matter of soil aggregate coatings. Journal of Hydrology and Hydromechanics, 64, 111-120.

García-Ruiz, J.M., Lana-Renault, N., 2011. Hydrological and erosive consequences of farmland abandonment in Europe, with special reference to the Mediterranean region A review. Agriculture, Ecosystems and Environment, 140, $317-338$.

Guo, X.P., Meng, M.J., Zhang, J.C., Chen, H.Y.H., 2016. Vegetation change impacts on soil organic carbon chemical composition in subtropical forests. Scientific Reports, 6, 29607. DOI: 10.1038/srep29607.

Hallett, P.D., 2008. A brief overview of the causes, impacts and amelioration of soil water repellency - a review. Soil \& Water Res., 3, Special Issue 1, S21-S29.

Hallett, P.D., Young, I.M., 1999. Changes to water repellence of soil aggregates caused by substrate-induced microbial activity. European Journal of Soil Science, 50, 35-40.

Hewelke, E., 2019. Influence of abandoning agricultural land use on hydrophysical properties of sandy soil. Water, 11, 525. DOI:10.3390/w11030525.

Iovino, M., Pekárová, P., Hallett, P.D., Pekár, J., Lichner, L., Mataix-Solera, J., Alagna, V., Walsh, R., Raffan, A., Schacht, K., Rodný, M., 2018. Extent and persistence of soil water repellency induced by pines in different geographic regions. Journal of Hydrology and Hydromechanics, 66, $360-368$.

ISO 10390, 2005. Soil quality. Determination of pH. International Organization of Standardization, Geneva. (https://www.iso.org/standard/40879.html)

ISO 10693, 1995. Soil quality. Determination of carbonate content. Volumetric method. International Organization of Standardization, (https://www.iso.org/standard/18781.html)

ISO 10694, 1995. Soil quality. Determination of organic and total carbon after dry combustion (elementary analysis). International Organization of Standardization, Geneva. (https://www.iso.org/standard/18782.html)

ISO 11277,2009 . Soil quality. Determination of particle size distribution in mineral soil material. Method by sieving and sedimentation. International Organization of Standardization, Geneva. (https://www.iso.org/standard/54151.html)

Kodešová, R., Jirků, V., Kodeš, V., Mühlhanselová, M., Nikodem, A., Žigová, A., 2011. Soil structure and soil hydraulic properties of Haplic Luvisol used as arable land and grassland. Soil \& Tillage Research, 111, 154-161.

Kottek, M., Grieser, J., Beck, C., Rudolf, B., Rubel, F., 2006. World map of the Köppen-Geiger climate classification updated. Meteorologische Zeitschrift, 15, 259-263.

Leelamanie, D.A.L., Nishiwaki, J., 2019. Water repellency in Japanese coniferous forest soils as affected by drying temperature and moisture. Biologia, 74, 127-137.

Lichner, L., Babejová, N., Dekker, L.W., 2002. Effects of kaolinite and drying temperature on the persistence of soil water repellency induced by humic acids. Rostlinná Výroba, 48, 203-207. 
Lichner, L., Hallett, P.D., Feeney, D., Dugová, O., Šír, M., Tesar̆, M., 2007. Field measurement of the impact of hydrophobicity on soil water transport under different vegetation over time. Biologia, 62, 537-541.

Lichner, L., Hallett, P.D., Drongová, Z., Czachor, H., Kovacik, L., Mataix-Solera, J., Homolák, M., 2013. Algae influence hydrophysical parameters of a sandy soil. Catena, 108, 5868.

Lichner, L., Felde, V.J.M.N.L., Büdel, B., Leue, M., Gerke, H.H., Ehlerbrock, R.H., Kollár, J., Rodný, M., Šurda, P., Fodor, N., Sándor, R., 2018. Effect of vegetation and its succession on water repellency in sandy soils. Ecohydrology, 11, Article Number: UNSP e1991.

McKissock, I., Walker, E.L., Gilkes, R.J., Carter, D.J., 2000. The influence of clay type on reduction of water repellency by applied clays: a review of some West Australian work. Journal of Hydrology, 231-232, 323-332.

Moret-Fernandez, D., Latorre, B., Giner, M.L., Ramos, J., Alados, C.L., Castellano, C., Lopez, M.V., Jimenez, J.J., Pueyo, Y., 2019. Estimation of the soil hydraulic properties from the transient infiltration curve measured on soils affected by water repellency. Catena, 178, 298-306.

Naveed, M., Ahmed, M.A., Benard, P., Brown, L.K., George, T.S., Bengough, A.G., Roose, T., Koebernick, N., Hallett, P.D., 2019. Surface tension, rheology and hydrophobicity of rhizodeposits and seed mucilage influence soil water retention and hysteresis. Plant and Soil, 437, 65-81.

NCSS 12 Statistical Software, 2018. NCSS, LLC. Kaysville, Utah, USA. ncss.com/software/ncss

Nik, K.S., Nael, M., Assadian, G., Sinegani, A.A.S., Kha, S.J., 2015. Soil organic carbon fractions as influenced by vegetation type and land management: A case study in semiarid rangelands of Hamedan, Iran. Eurasian Journal of Soil Science, 4, 2, 76-81.

Novák, V., Lichner, L', Zhang, B., Kňava, K., 2009. The impact of heating on the hydraulic properties of soils sampled under different plant cover. Biologia, 64, 483-486.

Oostindie, K., Dekker, L.W., Wesseling, J.G., Geissen, V., Ritsema, C.J., 2017. Impacts of grass removal on wetting and actual water repellency in a sandy soil. Journal of Hydrology and Hydromechanics, 65, 88-98.

Orfánus, T., Dlapa, P., Fodor, N., Rajkai, K., Sándor, R., Nováková, K., 2014. How severe and subcritical water repellency determines the seasonal infiltration in natural and cultivated sandy soils. Soil and Tillage Research, 135, 49-59.

Orfánus, T., Stojkovová, D., Rajkai, K., Czachor, H., Sándor, R., 2016. Spatial patterns of wetting characteristics in grassland sandy soil. Journal of Hydrology and Hydromechanics, 64, 167-175.
Queiroz, C., Beilin, R., Folke, C., Lindborg, R., 2014. Farmland abandonment: threat or opportunity for biodiversity conservation? A global review. Frontiers in Ecology and the Environment, 12, 288-296.

Pekárová, P., Pekár, J., Lichner, L., 2015. A new method for estimating soil water repellency index. Biologia, 70, 14501455.

Roper, M.M., 2005. Managing soils to enhance the potential for bioremediation of water repellency. Australian Journal of Soil Research, 43, 803-810.

Roper, M.M., 2006. Potential for remediation of water repellent soils by inoculation with wax-degrading bacteria in southwestern Australia. Biologia, 61, S358-S362.

Sepehrnia, N., Hajabbasi, M.A., Afyuni, M., Lichner, L., 2016. Extent and persistence of water repellency in two Iranian soils. Biologia, 71, 1137-1143.

Sepehrnia, N., Hajabbasi, M.A., Afyuni, M., Lichner, L', 2017. Soil water repellency changes with depth and relationship to physical properties within wettable and repellent soil profiles. Journal of Hydrology and Hydromechanics, 65, 99104.

Soil Survey Division Staff, 1993. Soil Survey Manual. Soil Conservation Service. U.S. Department of Agriculture Handbook, $18 \mathrm{p}$.

Šurda, P., Lichner, L', Nagy, V., Kollár, J., Iovino, M., Horel, Á., 2015. Effects of vegetation at different succession stages on soil properties and water flow in sandy soil. Biologia, 70, $1474-1479$.

Tinebra, I., Alagna, V., Iovino, M., Bagarello, V., 2019. Comparing different application procedures of the water drop penetration time test to assess soil water repellency in a fire affected Sicilian area. Catena, 177, 41-48.

Villarreal, R., Lozano, L.A., Melani, E.M., Salazar, M.P., Otero, M.F., Soracco, C.G., 2019. Diffusivity and sorptivity determination at different soil water contents from horizontal infiltration. Geoderma, 338, 88-96.

WRB, 2014. World Reference Base for Soil Resources 2014. World Soil Resources Reports No. 106. Rome, 192 p.

Zhang, R., 1997. Determination of soil sorptivity and hydraulic conductivity from the disk infiltrometer. Soil Science Society of America Journal, 61, 1024-1030.

Zhao, J., Li, S.P., He, X.Y., Liu, L., Wang, K.L., 2014. The soil biota composition along a progressive succession of secondary vegetation in a karst area. PLoS ONE, 9, 11, e112436.

Received 6 September 2019 Accepted 6 December 2019 